\title{
Peran Sosial Politik Bintara Pembina Desa (BABINSA) di Kabupaten Pandeglang.
}

\section{Esty Erviyanti}

Ilmu Pemerintahan, Fakultas Ilmu Sosial dan Ilmu Politik, Universitas Sultan Ageng Tirtayasa erviyantiesty5@yahoo.com

\section{Wahyu Kartiko Utami}

Ilmu Pemerintahan, Fakultas Ilmu Sosial dan Ilmu Politik, Universitas Sultan Ageng Tirtayasa wahyu.kartiko@untirta.ac.id

\begin{abstract}
Abstrak
penelitian ini membahas peran sosial politik Tentara Nasional Indonesia (TNI, tentara Indonesia) di tingkat desa dengan Bintara Pembina Desa (Babinsa, lembaga bimbingan desa) sebagai pelaksana pedoman wilayah. Lebih khusus, penelitian ini membahas lebih dalam tentang keterlibatan dan peran sosial politik Babinsa Komando Rayon Militer (Koramil, komando wilayah militer) 0113 / Cibaliung di Kabupaten Cibaliung selama 2017-2018. Tujuan dari penelitian ini adalah untuk mengetahui dan memahami peran dan pola keterlibatan Babinsa Cibaliung dalam kehidupan sosial politik desa, serta dampaknya terhadap pembangunan desa. Teori besar yang digunakan adalah teori hubungan militer-sipil Samuel P. Huntington dengan fokusnya pada kontrol sipil atas militer, di mana ada dua kategori kontrol sipil, yaitu: kontrol sipil subyektif dan kontrol sipil objektif. Selain itu, teori profesionalisme militer dan teori hegemoni Gramsci juga digunakan sebagai analisis dalam penelitian ini. Metode penelitian yang digunakan adalah metode penelitian kualitatif dengan pendekatan fenomenologis. Hasil penelitian menunjukkan bahwa kontrol sipil atas hubungan militer-sipil di Kabupaten Pandeglang adalah kontrol sipil yang obyektif yang menekankan keseimbangan antara kekuatan militer dan wewenang pemerintah sipil. Babinsa Cibaliung secara harfiah termasuk dalam jenis militer revolusioner, yang berarti bahwa pengetahuan profesional Babinsa ditujukan pada nilai-nilai sosial dan politik. Babinsa juga berperan dalam penyampaian wacana hegemoni negara di desa-desa.
\end{abstract}

Kata kunci: Babinsa cibaliung, militer, hubungan militer-sipil, profesionalisme.

\section{Abstract}

This paper examines the social political role of the Tentara Nasional Indonesia (TNI, Indonesian army) at the village level with the Bintara Pembina Desa (Babinsa, village guidance agency) as the executor of territorial guidance. More specifically, this paper discusses more deeply about the involvement and social political role of Babinsa of Komando Rayon Militer (Koramil, military command of territory) 0113/Cibaliung in 
Cibaliung District during 2017-2018. The purpose of this research is to know and understand the roles and pattern of involvement of the Cibaliung's Babinsa in the social political life of village, as well as its impact on village development. The grand theory used is Samuel P. Huntington's military-civil relations theory with its focus on civilian control over military, where there are two categories of civilian control, namely: subjective civilian control and objective civilian control. In addition, the theory of military professionalism and the theory of Gramsci's hegemony were also used as analysis blades in this research. The research method used is a qualitative research method with a phenomenological approach. The results of the research indicate that civilian control of military-civil relations in Cibaliung District is an objective civilian control that emphasizes the balance between military power and the authority of the civilian government. Babinsa of Cibaliung is literally included in the revolutionary military type, which means that Babinsa's professional knowledge is aimed at social and political values. Babinsa also plays a role in the delivery of state's hegemony discourses in villages.

Keywords : Babinsa of Cibaliung, military, military-civil relations, professionalism.

\section{Pendahuluan}

Militer merupakan satuan ber-senjata milik negara yang secara garis besar bertugas untuk menjaga per-tahanan dan keamanan suatu negara. Salah satu negara yang menjadikan militer sebagai alat pertahanan negara ialah Negara Republik Indonesia, yang umum disebut dengan Tentara Nasional Indonesia (TNI).

Meskipun demikian, pada fakta-nya militer Indonesia tidak hanya berkecimpung di bidang pertahanan saja. TNI Angkatan Darat (AD) me-mainkan peran dalam ranah sosial politik tidak hanya di tingkat nasional saja. Selaras dengan konsep desentra-lisasi yang dianut oleh negara Indonesia, TNI pun memiliki struktur kedaerahan sendiri yang secara administratif ada di setiap tingkat daerah. Konsep tersebut dinamakan dengan Pembinaan Teritorial.

Komando Rayon Militer (Koramil) merupakan pangkalan TNI setingkat kecamatan. Meski Koramil pangkalan militer terendah setingkat kecamatan, akan tetapi masih ada bagian dari TNI AD yang ditugaskan di tingkat desa. Bintara Pembina Desa atau Babinsa adalah bagian dari pembinaan teritorial TNI AD di bawah naungan Koramil, bertugas untuk melaksanakan pembinaan teritorial TNI AD di desa.

Kecamatan Cibaliung yang se-cara administratif termasuk ke dalam wilayah Kabupaten Pandeglang meru-pakan salah satu wilayah pembinaan teritorial TNI AD. Koramil 0113/ Cibaliung melalui Babinsa Cibaliung melaksanakan tugas pembinaan teri-torial di dua wilayah administratif, yakni Kecamatan Cibaliung dan Kecamatan Cibitung. Namun yang menjadi sorotan adalah pelaksanaan pembinaan teritorial di Kecamatan Cibaliung.

Namun dalam menjalankan tugasnya, terdapat beberapa kondisi yang menjadi hambatan dan per-masalahan tersendiri. Pertama, di-ketahui bahwa 
Koramil Cibaliung hingga saat ini menaungi 19 desa. Akan tetapi, angka tersebut tidak sebanding dengan jumlah personil Babinsa Koramil Cibaliung yang pada tahun 2017 hanya beranggotakan 16 orang, dengan komposisi 3 orang pimpinan dan 13 orang Babinsa. Akibatnya, komposisi yang ada tidak dapat dikatakan ideal, karena idealnya adalah komposisi 1:1.

Kedua, dana operasional yang diberikan oleh negara masih minim. Babinsa Koramil Cibaliung pada tahun 2017 memperoleh tunjangan operasional sebesar Rp.50.000,00 setiap bulannya. Besaran nominal tersebut nyatanya tidak dapat menutupi kebutuhan yang ada. Ini dikarenakan untuk dapat melaksana-kan tugasnya dengan turun ke desa disertai dengan jarak yang cukup jauh.

Ketiga, Babinsa Koramil Ciba-liung masih menerima insentif dari masyarakat setempat, terutama peme-rintah desa. Insentif yang diberikan dapat berupa uang tunai dan/atau barang. Keempat, keterlibatan Babin-sa dalam program ketahanan pangan di bidang pertanian. Akibatnya fungsi militer di desa sebagai penjaga ketahanan dan kedaulatan negara di tingkat desa menjadi rancu. Program pendampingan pertanian di Keca-matan Cibaliung sendiri telah di-laksanakan sejak tahun 2017.

Selain keterlibatannya dalam bidang pertanian desa, TNI melalui Babinsa pun turut melibatkan diri dalam bidang-bidang lainnya. Misal-nya, di Koramil Cibaliung sendiri memiliki program-program tahunan seperti kegiatan bakti sosial, karya bakti, TMMD (TNI Manunggal Membangun Desa), dan lain-lain.

Penelitian ini secara spesifik memiliki fokus terhadap pelaksanaan tugas Babinsa Koramil Cibaliung di Kecamatan Cibaliung dalam konteks pembangunan desa serta bagaimana peran sosial politik Babinsa dapat memengaruhi hubungan militer-sipil di Kecamatan Cibaliung.

\section{Kerangka Teori}

\section{Otonomi Militer sebagai Asal Mula Kekuatan Politik Militer Indonesia}

Otonomi militer Indonesia su-dah ada bahkan sejak awal terbentuk-nya militer Indonesia itu sendiri. Di-katakan otonom karena militer Indo-nesia pada faktanya menciptakan dirinya sendiri, tidak oleh pemerintah maupun partai politik. Dalam sejarah-nya, Said (2001:2) mengemukakan bahwa militer Indonesia terbentuk, mempersenjatai dan mengorganisasi-kan diri bermodalkan, antara lain, tenaga-tenaga pemuda yang telah mendapatkan latihan dan senjata-senjata militer Jepang yang berhasil mereka rampas setelah proklamasi.

Otonomi militer yang menguat di bawah kepemimpinan Panglima Besar Soedirman menjadikan militer Indonesia sebagai salah satu kekuatan politik penting negara. Lemahnya lembaga sipil, dinamika sistem pe-merintahan, antagonisme politik antar kubu di parlemen, hingga ancaman serangan Belanda menyebabkan kondisi negara dan pemerintahan tidak stabil juga mengendurkan kontrol sipil atas militer. Posisi militer Indonesia pada masa revolusi, khususnya 
masa perang gerilya tahun 1948-1949, menempatkan hubungan militer-sipil pada titik di mana militer mendominasi sipil.

\section{Potret Pembinaan Teritorial TNI AD Masa Kini}

Bintara Pembina Desa (Babin-sa) merupakan unsur terkecil dari eksistensi militer Indonesia yang hadir di tengah-tengah masyarakat. Keberadaannya, selain untuk me- laksanakan tugas pertahanan, juga untuk berbaur dengan masyarakat dan pemerintah daerah setempat. Hal ini merupakan hal ditemui di negara-negara lain, di mana militer berperan penting dalam kehidupan sosial politik masyarakat kecil.

Mendekatkan diri dan berbaur dengan masyarakat sipil merupakan salah satu tugas yang diemban oleh Babinsa. Upaya pembinaan dilakukan oleh Babinsa melalui pembinaan teri-torial dengan menggunakan pen-dekatan Bakti TNI dan Komunikasi Sosial. Kedua pendekatan tersebut membuat TNI sebagai pembina teritorial harus berhubungan atau ber-interaksi dengan masyarakat secara langsung. Dalam pelaksanaannya, pembinaan teritorial mengedepankan 4 (empat) aspek, yakni Persuasif, Edukatif, Pragmatif, dan Komunikatif (TNI Angkatan Darat, 2013:100-101).

\section{Metode Penelitian}

Penelitian ini menggunakan metode penelitian kualitatif dengan pendekatan fenomenologi (Creswell, 2007). Metode penelitian kualitatif memiliki keunggulan berupa pen-dalaman penelitian melalui pendekat-an secara langsung dengan objek penelitian.

Dalam pengambilan data, peneliti menggunakan tiga teknik pengumpulan data, yaitu: 1) obser-vasi; 2) wawancara; dan 3) studi pus-taka. Ketiga teknik pengumpulan data tersebut merupakan teknik pengum-pulan data dalam penelitian kualitatif yang dapat diamati oleh panca-indera (Hikmawan, 2014).

Sementara untuk menganalisa data, dalam penelitian ini digunakan teknik analisa triangulasi data. Tri-angulasi data yang digunakan oleh peneliti kali ini adalah triangulasi sumber (narasumber berbeda-beda) dan triangulasi metode (metode berbeda-beda). Selain itu dalam pendekatan fenomenologi pembukaan data merupakan sebuah analisis yang mencoba melihat lebih dalam untuk meahami dan menghayati data tersebut (Hikmawan, 2017a).

Menggunakan teknik analisa data triangulasi sumber, peneliti memperoleh data dan menganalisanya dari tiga unsur berbeda, yakni: 1) Babinsa Koramil Cibaliung; 2) Pemerintah Desa; serta 3) masyarakat desa. Dengan menggunakan teknik analisa data triangulasi metode, peneliti memperoleh data dan menganalisa data tersebut dari tiga metode berbeda, yakni observasi, wawancara, dan studi pustaka. Untuk dapat memperoleh data melalui metode wawancara, peneliti menggunakan teknik snowball sampling. Teknik snowball sampling adalah suatu 
metode untuk meng- identifikasi, memilih, dan mengambil sampel dalam suatu jaringan atau rantai hubungan yang menerus (Neuman, 2003). Adapun informan dalam penelitian ini terdiri dari tiga unsur yang berbeda, yakni Babinsa Koramil Cibaliung, Pemerintah Desa, dan masyarakat desa.

\section{Hasil dan Diskusi}

\section{Peran Sosial Politik Babinsa Koramil Cibaliung dalam Pembangunan Desa di Kecamatan Cibaliung}

Babinsa merupakan ujung tom-bak dari TNI AD. Demikian karena dengan ditempatkan paling dekat dengan masyarakat, Babinsa diwajib-kan mengetahui dan memahami si-tuasi terkini yang ada. Dalam artian, segala sesuatu yang terjadi di desa, baik di pemerintahan desa maupun ma-syarakat desa itu sendiri, Babinsa perlu mengetahuinya secara detail.

Babinsa Koramil Cibaliung me-nitikberatkan fungsinya terhadap pengkajian kondisi sosial di desa binaan. Kondisi sosial tersebut me-liputi beberapa bidang, yang juga acap kali disebut dengan sebutan "IPOLESOSBUDHANKAM". Ungkapan tersebut merupakan akronim dari beberapa kata lainnya, yakni meliputi Ideologi, Politik, Ekonomi, Sosial, Budaya, Pertahanan, dan Ke-amanan. Babinsa juga patut mema-hami, mengawasi, dan bertindak (apa-bila diperlukan) pada setiap kondisi dan situasi, baik yang sudah terjadi, sedang terjadi, dan yang akan terjadi di wilayah tempatnya bertugas.

Data dan informasi desa binaan adalah hal terpenting yang perlu diketahui dan dipahami oleh Babinsa. Kondisi masyarakat dan Pemerintah Desa juga perlu untuk diketahui Babinsa. Sehingga, dapat dikatakan bahwa Babinsa dituntut untuk menge- tahui desa secara menyeluruh.

Pemerintah desa dalam melak-sanakan tugas pembangunan desa juga melibatkan unsur-unsur lainnya, salah satunya adalah Babinsa. Dalam kegiatan musyawarah desa, rapat RPJMDes (Rencana Pembangunan Jangka Menengah Desa), maupun rapat-rapat lainnya, Pemerintah Desa selalu mengundang Babinsa untuk hadir. Kehadiran Babinsa di rapat-rapat desa tersebut tidak hanya sekedar hadir saja, akan tetapi juga memberikan masukan, arahan, bahkan solusi. Tidak jarang pula Babinsa melaporkan situasi terkini masyarakat kepada Pemerintah Desa, terutama dengan hal-hal yang berhubungan dengan kesulitan masyarakat desa.

Garis yang menghubungkan an-tara Pemerintah Desa dengan Babinsa adalah garis koordinasi. Sehingga, apa yang dilakukan oleh Babinsa terhadap desa perlu diketahui oleh Pemerintah Desa dan apa yang di-lakukan oleh Pemerintah Desa juga perlu diketahui oleh Babinsa. Hal yang diberitahukan adalah hal-hal yang berkaitan dengan kondisi ling-kungan desa dan masyarakat.

Selain itu, Babinsa juga ikut dalam kegiatan lainnya, seperti gotong royong, 
kegiatan penyuluhan desa, sosialisasi, dan lain-lain. Babinsa hadir di sana, baik hanya sebagai audien, tamu undangan, pengamanan, atau bahkan menjadi narasumber apabila memang dibutuh-kan. Diundang atau tidak diundang.

Dalam kegiatan-kegiatan ter-sebut, terdapat beberapa kesempatan di mana pihak Pemerintah Desa memberikan insentif, baik berupa uang maupun barang kepada Babinsa. Insentif secara bahasa berarti tambahan penghasilan (uang, barang, dan sebagai-nya) yang diberikan untuk meningkatkan gairah kerja. Namun, Pemerintah Desa di Keca-matan Cibaliung enggan menyebut-nya sebagai pemberian insentif. Mereka mengartikan istilah insentif sebagai pemberian honorarium yang dialokasikan dalam anggaran tahunan secara pribadi atau dalam artian gaji (salary). Maka dari itu, mereka menolak atau tidak mengakui telah memberikan insentif kepada Babinsa.

Berdasarkan pengamatan pri-badi peneliti, besaran insentif yang diberikan oleh Pemerintah Desa dalam bentuk uang biasanya diperoleh kisaran Rp.20.000,00 hingga Rp.200.000,00. Tidak hanya dalam bentuk uang, insentif pun di-berikan dalam bentuk barang. Misal-nya: makanan, rokok, dan lain-lain.

Selain oleh Pemerintah Desa, insentif sebagai tanda terima kasih juga ada yang berasal dari masyarakat. Tetapi besaran nominal (apabila berbentuk uang) yang diberikan tidak sebesar yang diberikan oleh Pemerin-tah Desa. Hal ini diamini oleh Danramil Moch. Dermawan (wawan-cara bersama, 2017) yang mengung-kapkan bahwa memang ada saja masyarakat yang memberikan 'imbalan' kepada Babinsa. Misalnya, memberikan imbalan sebagai 'ganti pulpen', 'ganti buku', 'beli kopi' atau bahkan 'uang rokok'.

Meskipun demikian, Babinsa tidak diperbolehkan (dilarang) untuk meminta imbalan dalam bentuk apapun kepada pemerintah maupun masyarakat desa, apalagi sampai memaksa. Hanya saja apabila ada pihak pemerintah atau masyarakat yang memberikan perhatian lebih seperti itu, Babinsa dipersilakan untuk memilih: menerima atau menolak.

Pemberian insentif tersebut juga ada yang didasari dengan pemak-luman dari pihak Pemerintah Desa, karena mengetahui tunjangan opera-sional Babinsa tiap bulannya hanya sebesar Rp.50.000,00. Dengan jarak desa yang jauh, perjalanan yang cukup memakan waktu, maka dianggap wajar apabila pihak desa memberikan sejumlah uang sebagai tanda terima kasih. Hal tersebut tentu mengindikasikan tindakan gratifikasi yang memang berlainan dengan undangundang negara. Terlepas dari hal tersebut, budaya masyarakat yang senang memberikan imbalan kepada aparatur negara inilah yang dapat memicu tindakan serupa lainnya.

Pemerintah Desa di Kecamatan Cibaliung menyatakan bahwa mereka masih membutuhkan adanya Babinsa. Selain karena membantu Pemerintah Desa, juga karena membantu masya-rakat desa. Beberapa program yang digalakan TNI bahkan memberikan dampak yang positif kepada masya-rakat. Sehingga, 
Pemerintah Desa se- lalu mendukung program-program yang dibawa oleh Babinsa, terutama program Bakti TNI.

Meskipun Pemerintah Desa memberikan banyak ulasan yang positif terhadap Babinsa, namun beberapa masih merasa kurang puas dengan kinerja Babinsa di desanya. Ada yang mengeluhkan tentang jarangnya tatap muka dengan Babinsa. Selain itu, ada juga yang mengeluh tentang ketidakpastian siapa Babinsa di desanya karena kurang komunikasi apabila terjadi rotasi pergantian Babinsa.

\section{Implementasi Bakti TNI di Kecamatan Cibaliung}

Bakti TNI merupakan program kegiatan TNI yang sasarannya adalah masyarakat. Telah banyak program Bakti TNI yang dilaksanakan di Kecamatan Cibaliung. Program ke-giatan bakti sosial tersebut merupakan program turunan dari pusat yang dilimpahkan kepada Koramil dan Babinsa selaku pelaksana di lapangan.

Program kegiatan buka jalan adalah satu dari sekian program yang dilaksanakan oleh Babinsa. Kegiatan ini biasanya merupakan usulan dari desa setempat, di mana akses jalan memang masih menjadi kendala tersendiri bagi masyarakat desa. Adanya pembukaan bertujuan untuk mendukung mobilitas masyarakat.

Selanjutnya kegiatan sosialisasi KB Kes (Keluarga Berencana dan Kesehatan). Dilaksanakan atas kerja-sama dengan Dinas Kesehatan atau Puskesmas setempat. Babinsa mem-berikan sosialisasi kepada masyarakat terkait pentingnya menjaga kesehatan dan menggunakan alat kontrasepsi. Dalam kegiatan ini pula, masyarakat dapat melakukan pemeriksaan ke-sehatan dan pemasangan alat kontra-sepsi secara gratis.

Selain itu, Babinsa melalui program Bakti TNI juga melaksana-kan kegiatan operasi katarak dan bibir sumbing gratis untuk masyarakat kurang mampu yang membutuhkan. Terselenggara atas kerjasama dengan Dinas Kesehatan dan pihak swasta. Di samping itu, Babinsa juga bekerja-sama dengan Pemerintah Desa binaannya masing-masing untuk memperoleh data yang akurat terkait masyarakat desa yang berhak mendapatkan pengobatan gratis tersebut.

Operasi katarak dan bibir sum-bing gratis di Kecamatan Cibaliung selalu diadakan setidaknya satu kali dalam satu tahun. Tugas Babinsa di sana selain mengakomodir masya-rakat penerima bantuan, juga bertugas mendampingi dan mengantarkan pe-nerima bantuan ke rumah sakit yang telah ditentukan sebelumnya. Biasa-nya Babinsa Cibaliung menyediakan transportasi, mengurus administrasi, serta mencarikan tempat untuk menginap (apabila diperlukan). Dana yang diperoleh pun merupakan hasil akumulasi dari kerjasama antara TNI, Dinas Kesehatan, dan pihak swasta.

Terakhir, adalah program kegia-tan swasembada atau ketahanan pa-ngan (food security). Program ini sejatinya adalah program nasional yang memiliki fokus 
di bidang per-tanian. Hal tersebut dilakukan sebagai upaya Pemerintah Pusat untuk dapat meningkatkan produksi pertanian agar negara tidak melulu melakukan impor bahan makanan dari luar negeri.

Bersama Balai Penyuluhan Per-tanian (BPP) Kecamatan Cibaliung, Koramil Cibaliung melakukan kerja sama untuk melaksanakan program ketahanan pangan. Hal utama yang dilakukan oleh Babinsa adalah me-lakukan pengamanan, pengawasan dan pendampingan terhadap distribusi bahan pokok tani yang disalurkan dari pusat ke desa-desa. Bahan pokok tani yang dimaksud dapat berupa benih, pupuk, atau bahkan alat-alat tani. Kegiatan tersebut mulai aktif di-lakukan sejak tahun 2017.

Selain bertugas untuk memberikan pengamanan dan pengawasan, Babinsa Cibaliung juga ikut mem-berikan penyuluhan terkait cara ber-cocok tanam yang baik kepada para petani. Pemberian penyuluhan bertani oleh Babinsa juga tidak dilakukan secara mandiri. Dalam pelaksanaan-nya, Babinsa wajib didampingi oleh salah seorang penyuluh pertanian. Ilmu tentang pertanian yang Babinsa miliki pun berasal pihak BPP, mulai dari teknik hingga teknologinya.

Achmad Bahrudin (Koordinator BPP Cibaliung, 2019) mengakui bahwa kemampuan Babinsa meng-gerakkan para petani telah membawa hasil yang positif. Motivasi para pe-tani Cibaliung di masing-masing desa mengalami peningkatan. Begitupun dengan produksi pertanian. Oleh karena itu, kolaborasi antara BPP dan Koramil Cibaliung dapat dikatakan berjalan dengan baik karena men-dukung upaya program ketahanan pangan nasional dengan mendorong dan mengoptimalisasi potensi para petani di Kecamatan Cibaliung.

Terkait keterlibatan militer di bidang pertanian, Letkol Inf. Solih (dalam tni.mil.id, 20 April 2017) menegaskan bahwa kehadiran Babinsa TNI AD bukan sebagai penyuluh pertanian, akan tetapi TNI AD adalah motivator, fasilitator, dinamisator, dan inovator bagi kelompok tani di lapangan.

\section{Model Profesionalisme Babinsa dan Hubungan Militer-Sipil di Kecamatan Cibaliung}

Profesionalisme militer dalam teorinya terdapat 2 (dua) kategori (Effendy, 2008:302). Pertama, profe-sionalisme lama (old professionalism) oleh Huntington yang menjadikan militer hanya sebagai alat pertahanan negara tanpa dilibatkan ke dalam urusan politik negara. Kedua, profesionalisme baru (new professio-nalism) oleh Stephan diartikan se-bagai bentuk profesionalisme militer yang melibatkan diri ke dalam ke- hidupan sosial politik negara (Widiyanto, Hikmawan, \& Riswanda, 2019).

Model profesionalisme yang ditunjukkan oleh TNI dewasa ini termasuk ke dalam kategori profe-sionalisme baru. Nampak jelas ter-lihat dari keberadaan pembinaan teritorial yang ikut andil dalam upaya pembangunan daerah. Hal tersebut bermuara kepada pernyataan bahwa militer Indonesia kini tidak hanya 
menjadi manager of violence saja, akan tetapi menjadi satu dari sekian aktor yang tampil di panggung sosial politik negara. Konklusi dari pengkategorian profesionalisme baru dalam tubuh TNI ini berangkat dari keterlibatan Babinsa dalam kehidupan sosial politik desa (Hikmawan, Indriyany, \& Mayrudin, 2019). Babinsa adalah tingkatan militer Indonesia yang menempatkan diri di dalam masyarakat dan ber-interaksi secara langsung dengan mereka. Sehingga, tidak dapat diragukan lagi apabila TNI menganut paham profesionalisme militer baru.

Sebagaimana yang telah di-bahas pada bagian sebelumnya, keberadaan Babinsa tidak hanya diperuntukkan menjaga keamanan desa saja. Selain menjaga keamanan wilayah binaan, Babinsa juga terlibat aktif dalam urusan-urusan masyarakat yang bersifat non-militer. Penge-tahuan akan kondisi sosial dan kemampuan untuk melakukan komu-nikasi sosial menjadi kunci suksesi tugas Babinsa di lapangan.

Meninjau dari fakta tersebut, tipe militer (Burhan Magenda dalam Iswandi, 2000:5-14) Babinsa Ciba-liung adalah tipe militer revolusioner. Demikian karena pengetahuan profesional yang dimiliki Babinsa di-tujukan pada nilai-nilai sosial dan politik. Pengetahuan yang Babinsa miliki tentu dalam realisasinya telah dan akan diterapkan kepada masya-rakat dan desa. Bakti TNI dan komu-nikasi sosial merupakan satu dari sekian sarana implementasi penge-tahuan tersebut.

Dalam pelaksanaan tugas, sikap disiplin yang ditunjukkan oleh Babin-sa Koramil Cibaliung berbeda antara satu dengan lainnya. Ada yang secara disiplin memenuhi tugasnya dengan rutin setiap minggu berkunjung ke desa binaan. Ada yang hanya rutin berkomunikasi melalui telepon atau pesan singkat. Bahkan ada yang sangat jarang berkunjung ke desa binaan sepanjang tahun 2017. Dampaknya, ada desa yang bahkan tidak tahu siapa Babinsa yang bertugas saat itu di desanya sendiri.

Adanya permasalahan tersebut tentu dilatarbelakangi oleh beberapa faktor. Pertama, dana operasional yang belum memadai. Nominal dana operasional sebesar Rp.50.000,00 ternyata tidak dapat menjamin semangat kerja dan konsistensi Babinsa terhadap pelaksanaan tugas secara optimal. Kedua, jarak desa binaan yang jauh. Menyambung dari faktor pertama, jarak tempuh yang jauh juga menjadi kendala bagi Babinsa dalam menjalankan tugasnya. Ditambah dengan dana operasional yang belum memadai, menyebabkan Babinsa jarang untuk turun ke desa.

Ketiga, kondisi perekonomian keluarga yang kurang baik. Ini juga bisa menjadi permasalahan tersendiri, karena tidak semua Babinsa memiliki tingkat ekonomi keluarga yang baik. Bahkan tidak jarang pula istri Babinsa yang membuka usaha kecil- kecilan untuk membantu dalam hal me-menuhi kebutuhan keluarga sehari-hari. Keempat, personalitas. Faktor ini merupakan faktor yang bersifat pribadi dan berhubungan dengan pe-rilaku alami manusia. Timbulnya rasa malas, kurang peduli, mementingkan urusan pribadi, dan lain sebagainya menjadi 
komponen pendukung mun-culnya faktor ini.

Berdasarkan pengumpulan data dan fakta di lapangan, kontrol sipil dalam hubungan militer sipil di Kecamatan Cibaliung termasuk ke dalam kategori kontrol sipil objektif (Huntington, 1985). Kontrol sipil objektif menyajikan keseimbangan antara kekuasaan militer dengan pemerintahan sipil. Konsep ini juga memaksimumkan profesionalisme militer dan kendali sipil atas militer.

Kontrol sipil yang objektif di Kecamatan Cibaliung dibuktikan de-ngan kekuasaan militer yang rendah atau dalam artian tidak mendominasi. Garis yang terhubung antara Koramil dengan kecamatan maupun antara Babinsa dan desa adalah garis koordinasi. Dari pemahaman tersebut mu-lai terbentuk sebuah keseimbangan, di mana kedua institusi akan saling menghargai tugas dan fungsinya masing-masing.

Pemerintah Desa di Kecamatan Cibaliung pada faktanya tidak me-nelan mentah- mentah apa yang di-sarankan oleh Babinsa, apalagi masukan yang berkaitan dengan pem-bangunan desa. Otoritas sebagai pe-megang pemerintahan di tingkat desa masih ada dan tidak begitu saja bisa didominasi. Keterlibatan Babinsa da-lam kehidupan sosial politik masya-rakat desa memiliki batasannya sendiri yang dibangun oleh peme- rintah sipil dari tingkat nasional hingga desa.

\section{Kesimpulan}

\section{Babinsa dan Miniatur Hegemoni Negara di Desa}

Hegemoni (Gramsci dalam Simon, 2004:19-20) merupakan suatu konsep yang menggambarkan betapa besarnya kekuasaan negara untuk dapat memengaruhi dan mendoktrin warga negaranya. Membenarkan hal yang dianggap benar, melarang hal yang dianggap salah. Pembenaran yang dikontruksikan tersebut kemu-dian diikuti oleh warga negaranya dan dijadikan sebuah landasan untuk bertindak dalam kehidupan sehari-hari (Hikmawan, 2017b).

Militer atau angkatan bersenjata pada hakikatnya merupakan satu dari sekian sumber kekuasaan negara yang memiliki kekuatan besar. Didukung dengan kemahiran dan suplai pelbagai macam senjata, militer menjadi dual-isme yang nyata bagi masyarakat atau warga negaranya. Di satu sisi, militer bisa saja menjadi pelindung bagi masyarakat. Sementara di sisi lain, militer dapat menjadi ancaman dan musuh masyarakat.

Sebagai salah satu sumber kekuasaan negara, TNI dewasa ini tidak hanya digunakan sebagai alat koersi dalam tindakan kekerasan untuk membuat masyarakat taat akan hukum. Cara lain yang dilakukan adalah melalui pendekatan kepada masyarakat sipil dalam konteks yang lebih halus. Contoh yang paling mudah ditemui adalah dengan kehadiran dan keterlibatan Babinsa dalam kehidupan sosial politik masyarakat.

Babinsa Koramil Cibaliung me-lalui komunikasi sosial kepada ma-syarakat desa Kecamatan Cibaliung memediasi hegemoni negara dalam rangka penegasan 
kedaulatan negara atas warga negaranya. Negara secara tidak langsung menuntut warga ne-gara atas masyarakatnya untuk patuh dan tunduk terhadap hukum, kebijak- an, dan keputusan yang negara buat. Pemberlakuan hukum positif juga merupakan hal yang wajib dipatuhi oleh masyarakat. Bahkan Budiardjo (2013:54) pun menuturkan bahwa negara menuntut loyalitas yang mutlak dari warga negaranya.

Pembahasan tentang hegemoni nyatanya tidak akan terlepas dari wacana terkonstruksi (diskursus) yang membumbui hegemoni (Hikmawan \& Hidayat, 2016). Diskursus akan hadir apabila hegemoni tidak ditempuh dengan cara kekerasan (koersi). Lebih tepatnya, diskursus merupakan salah satu hegemoni secara intelektual yang dilancarkan melalui ide (pemikiran) yang dapat membuat perubahan. Diskursus akan melakukan pembenaran terhadap muatan ide secara terstruktur sehingga pemikiran tersebut dapat diterima dan dibenarkan (Hikmawan, 2017a)h.

Dalam lingkup desa di Keca-matan Cibaliung, peneliti mengindikasikan beberapa hal yang dapat dikatakan sebagai diskursus yang di-bawa oleh Babinsa. Pertama, me-ngenai slogan "Bersama Rakyat TNI Kuat". Slogan tersebut memberikan arti mendalam bahwa kekuatan TNI berasal dari rakyat dan akan semakin kuat jika didukung oleh rakyat. Ini mencitrakan militer yang pro rakyat, militer yang selalu berdiri untuk kepentingan rakyat dan negara.

Kedua, PKI adalah musuh bangsa dan negara. Pada tahun 2017 silam, terdapat instruksi yang turun dari pusat kepada Babinsa untuk melaksanakan kegiatan 'Nonton Bareng Film G30S/PKI', termasuk di Kecamatan Cibaliung.

Selain mengingatkan masya-rakat akan tragedi nasional di masa lampau, penayangan film kontro-versial tersebut memberikan pe-nekanan pada satu titik, yaitu PKI adalah musuh bangsa dan negara. Jika melihat kembali ke sejarah, TNI dan PKI bagaikan air dan minyak, tidak dapat bersatu dan saling menolak satu sama lain. Menjadi suatu hal yang patut disoroti juga, bagaimana upaya TNI dan negara untuk dapat menyam-paikan pemikiran kepada rakyat bahwa PKI adalah golongan terkejam sepanjang sejarah negara Indonesia.

Ketiga, Babinsa adalah komponen penting dalam pembangunan desa. Desa di Kecamatan Cibaliung sebagian besar menganggap bahwa Babinsa memiliki peranan yang cukup vital dalam pembangunan desa. Begitu pun Koramil Cibaliung yang juga beranggapan demikian. Anggap-an tersebut muncul dari pemikiran bahwa Babinsa mengetahui dan memahami masalah yang ada melalui interaksi-interaksinya dengan masya-rakat. Babinsa melakukan komunikasi sosial dan memahami kondisi sosial desa dan masyarakat desa, serta anggapan bahwa Babinsa lebih dekat dengan masyarakat dan kerap mem-berikan solusi terhadap permasalahan yang ada.

Desa, dalam pandangan militer, merupakan representasi dari negara. Desa dianalogikan sebagai organ tubuh manusia, yang apabila ter-proteksi dan terawat 
Volume 1 Issue 2, August 2019

http://hk-publishing.id/ijd-demos

dengan baik maka tubuh manusia tersebut akan terjaga kesehatannya (Purnamasari \& Ramdani, 2019). Artinya, desa sebagai bagian terkecil negara yang menopang keberlangsungan hidup suatu negara yang amat penting peranannya dan patut dijaga kedaulatannya. Oleh karena itu, desa merefleksikan negara, yang mana apabila desa aman, damai, tenteram, dan sejahtera, maka negara juga akan mengalami hal yang sama.

\section{Referensi}

Budiardjo, Miriam. (2013). Dasar-Dasar Ilmu Politik. Edisi Revisi. Cetakan ke-9. Jakarta: PT Gramedia Pustaka Utama.

Creswell, John W. (2007). Qualitative Inquiry and Research Design: Choosing Among Five Approaches. Second Edition. Thousand Oaks: Sage Publication, Inc.

Effendy, Muhadjir. (2008). Profesionalisme Militer: Profesionalisasi TNI. Malang: UMM Press.

Hikmawan, M. D. (2014). Politik Perbedaan : Demokrasi dalam Paradoks. Universitas Gdjah Mada.

Hikmawan, M. D. (2017a). Pluralisme Demokrasi Politik di Indonesia. Journal of Governance, 2(2), 223-247.

https://doi.org/http://dx.doi.org/10.31506/jog.v2i2.2678

Hikmawan, M. D. (2017b). Politik Perbedaan: Minnoritas dalam Implementasi Kebijakan. Journal of Indonesian Public Administration and Governance Studies (JIPAGS), 1(1), 88-98.

Hikmawan, M. D., \& Hidayat, R. (2016). Depoliticisation of Public Issue : Low

Degree of Government ' S Democratic Legitimacy. Journal of Governance, 1(1), 23 37. https:// doi.org/http://dx.doi.org/10.31506/jog.v1i1.1311

Hikmawan, M. D., Indriyany, I. A., \& Mayrudin, Y. M. (2019). Environmental Movement Against Mining Exploration in Bojonegara Serang Banten. https://doi.org/https:// doi.org/10.2991/icdesa-19.2019.57

Huntington, Samuel P. (1985). The Soldier and The State: The Theory and Politics of CivilMilitary Relations. London: The Belknap Press of Harvard University Press.

Iswandi. (2000). Bisnis Militer Orde Baru: Keterlibatan ABRI dalam Bidang Ekonomi dan Pengaruh-nya Terhadap Pembentukan Rezim Otoriter. Bandung: PT Remaja Rosdakarya.

Letkol Inf. Solih. 20 April 2017. Peran Babinsa dalam Swa-sembada Pangan. Diakses dari: www.tni.mil.id/view-112024-peran-babinsa-dalam-swasembada- 
Volume 1 Issue 2, August 2019

http:/ / hk-publishing.id/ijd-demos

pangan.html pada tanggal 4 Mei 2019 pukul 15:31 WIB.

Neuman, W. L. (2003). Social Research Methods, Qualitative and Quantitative Approaches. Fifth Edition. Boston: Pearson Education.

Purnamasari, H., \& Ramdani, R. (2019). Evaluasi Program Badan Usaha Milik Desa ( BUM DESA ) Oleh Dinas Pemberdayaan Masyarakat dan Desa di Kabupaten Karawang. International Journal of Demos, 1(1), 89-100.

Said, Salim. (2001). Militer Indonesia dan Politik: Dulu, Kini dan Kelak. Jakarta: Pustaka Sinar Harapan.

Simon, Roger. (2004). Gagasan-gagasan Politik Gramsci. Cetakan ke-4. Yogyakarta: Pustaka Pelajar.

TNI Angkatan Darat. (2013). Rangkuman Materi Pem-belajaran Pendidikan Pembentukan Bintara Khusus Babinsa. Bandung: Komando Daerah Militer III/Siliwangi.

Undang-Undang Dasar Negara Republik Indonesia Tahun 1945 (Amandemen).

Widiyanto, A., Hikmawan, M. D., \& Riswanda, riswanda. (2019). JSPG: Journal of Social Politics and Governance Implementasi Rencana Aksi Nasional Bela Negara Berdasarkan Instruksi Presiden Nomor 7 Tahun 2018 Oleh Dewan Ketahanan Nasional Republik Indonesia. Journal of Social Politics and Governance, 1(2), 95-115. 